\title{
KEISLAMAN DAN KEBANGSAAN: TELAAH PEMIKIRAN KH. HASYIM ASY'ARI
}

\author{
Muhammad Rijal Fadli; Ajat Sudrajat \\ Universitas Negeri Yogyakarta \\ rijalfadli.co@gmail.com; ajat@uny.ac.id
}

\begin{abstract}
This article analyzes KH.Hasyim Asy'ari's thought on Islam and (Indonesian) nationalism. The Islamic and nationalist thought of Hasyim Asy'ari is presented in a descriptive content analysis framed in a library study. The results show that the problem that emerges today in the life of the nation is the emergence of groups that put Islam and nationalism in opposition. Hasyim Asy'ari himself argue that the two elements of national life should not be disputed because they are in the same boat for the national interest. The Islamic thought of Hasyim Asy'ari has a traditional Islamic style that focuses on sufism, theology (ablussunah wal jama'ah) and fiqh. Asy'ari's nationalist thought has led to the emergence of political ideas used in the struggle to unite the people and to confront colonialism as well as an effort to fight for Indonesian independence.
\end{abstract}

Keywords: KH. Hasyim Asy'ari; Islam; Nationalism

\begin{abstract}
Abstrak: Artikel ini menalaab pemikiran KH. Hasyim Asy'ari mengenai keislaman dan kebangsaan. Pemikiran keislaman dan kebangsaan Hasyim Asy'ari disajikan dengan analisis konten deskriptif yang dibingkai dalam sebuah studi kepustakaan. Hasil penelitian menunjukkan babwa permasalahan yang mengemuka dewasa ini pada kehidupan bangsa Indonesia adalab munculnya golongan-golongan yang menempatkan keislaman dan kebangsaan (keindonesiaan) dalam pertentangan. Hasyim Asy'ari sendiri membantah bahwa kedua elemen kehidupan berbangsa tersebut tidak seharusnya dipertentangkan karena keduanya berada dalam satu konsep yang sama untuk kepentingan bangsa. Pemikiran keislaman Hasyim Asy'ari bercorak. Islam tradisional yang berfokus pada tasawuf, teologi (ablussunah wal jama'ah) dan fiqh. Pemikiran kebangsaan Asy'ari memunculkan banyak ide-ide politik yang digunakan dalam perjuangan untuk mempersatukan umat dan melakukan konfrontasi terbadap kolonialisme serta usaha dalam memperjuangkan kemerdekaan Indonesia.
\end{abstract}

Kata kunci: KH. Hasyim Asy'ari; Keislaman; Kebangsaan

\section{Pendahuluan}

Belakangan ini berbagai persoalan yang menimpa bangsa Indonesia merupakan akumulasi dari perjalanan sejarah berdirinya Negara Kesatuan Republik Indonesia. Hadir sosok tokoh pemersatu bangsa yakni KH. Hasyim Asy'ari yang dinobatkan sebagai tokoh pendiri bangsa. Peran dan pemikiran KH. Hasyim Asy'ari tidak bisa dikesampingkan begitu saja, sebab ia dalam perjalanan sejarah Indonesia hadir untuk menyatukan seluruh komponen masyarakat Indonesia. Mulai dari mendirikan organisasi Nahdlatul Ulama, menyatukan seluruh golongan Islam dalam 
MIAI, partai Islam dalam Masyumi dan melahirkan fatwa jihad atau dikenal dengan resolusi jihad dalam memperjuangkan kemerdekaan Indonesia. ${ }^{1}$

KH. Hasyim Asy'ari juga dikenal dengan tokoh par-excellence yang mampu mewariskan khazanah khas ala Indonesia. Melalui karya-karyanya, KH. Hasyim Asy'ari berhasil mengkontruksikan pemikiran dan perilaku masyarakat Indonesia dengan konsep keberagamaan khas Indonesia yang di satu sisi tidak lepas dari akarakar tradisi yang berkembang di Indonesia, dan di sisi lain KH. Hasyim Asy'ari tetap berpegang teguh kepada khazanah salafusshalih sunni. Inilah yang membuat keunikan dan perbedaan dengan tokoh-tokoh agama lainnya. ${ }^{2}$

KH. Hasyim Asy'ari dapat dikatakan sebagai seorang ulama besar yang kharismatik dan mempunyai pemikiran yang besar dalam bidang keagamaan dan kebangsaan. ${ }^{3}$ Ia telah menjadi uswatun hasanah baik dalam pemikiran, sikap, tingkah laku, maupun tutur bahasanya, sehingga dapat dijadikan panutan bagi masyarakat, baik pada masa lalu maupun untuk masa saat ini. Ia mempunyai peranan yang sangat besar dalam pemberdayaan umat sejak zaman penjajahan Belanda, Jepang maupun pada saat memperjuangkan kemerdekaan Indonesia. Menurut ketua PBNU KH. Said Aqil Siradj, ${ }^{4} \mathrm{KH}$. Hasyim Asy'ari sangat patut sekali dijadikan referensi dari ulama pesantren yang berjuang demi bangsa dan negara, baik dalam ranah keagamaan maupun kebangsaan.

Menurut Tim Pusat Kajian Pemikiran KH. Hasyim Asy'ari Tebu Ireng, akhirakhir ini terjadi fenomena yang menimpa terhadap kehidupan bangsa Indonesia, dengan kembali munculnya golongan-golongan yang mempertentang keislaman dan kebangsaan (keindonesiaan). ${ }^{5}$ Ada satu pihak mengarah dengan gerakan radikal berusaha membawa bangsa ini kepada negara agama secara skriptualis dengan munculnya istilah NKRI bersyariah. Sementara pihak lain dari kelompok gerakan liberal dan kiri yang berusaha menjadikan bangsa ini menjadi bangsa sekuler dan komunisme.

Padahal masalah keagamaan dan kebangsaan tidak bisa dipertentangkan begitu saja, keduanya harus saling melengkapi demi kesejahteraan bangsa dan kenyaman dalam menjalankan perintah agama. ${ }^{6} \mathrm{KH}$. Hasyim Asy'ari sendiri telah membuktikan bahwa antara keislaman dengan keindonesiaan tidak boleh

${ }^{1}$ Abdul Hadi, K.H. Hasyim Asy'ari: Sehimpun Cerita, Cinta, Dan Karya Maha Guru Ulama Nusantara, Cetakan pertama (Baturetno, Banguntapan, Yogyakarta: Diva Press, 2018), 35.

2Syamsun Ni'am, Wasiat Tarekat: Hadratus Syaikh Hasyim Asy'ari, Cet. 1 (Sleman, Yogyakarta: Ar-Ruzz Media, 2011), 102.

${ }^{3}$ Ahmad Khoirul Fata and M Ainun Najib, 'Kontekstualisasi Pemikiran KH. Hasyim Asy'ari Tentang Persatuan Umat Islam', MIQOT: Jurnal Ilmu-ilmu Keislaman 38, no. 2 (Desember 2014): 319334, https://doi.org/10.30821/miqot.v38i2.65.

${ }^{4}$ Aguk Irawan Mn, Penakluk Badai: Novel Biografi K.H. Hasyim Asy'ari, Cet. 1 (Depok: Global Media Utama, 2012), xxviii.

${ }^{5}$ Tim Pusat Kajian Pemikiran KH. Hasyim Asy'ari Tebuireng, Sikap Keislaman Dan Kebangsaan Hadratussyaikh KH. M. Hasyim Asy'ari, Cetakan I (Jombang, Indonesia: Pustaka Tebuireng, 2018), ix.

${ }^{6}$ Sulaiman Kurdi, "MASYARAKAT IDEAL DALAM AL-QUR'AN (Pergulatan Pemikiran Ideologi Negara Dalam Islam Antara Formalistik Dan Substansialistik)," Khazanab: Jurnal Studi Islam Dan Humaniora 13, no. 2 (May 26, 2017): 41, https://doi.org/10.18592/khazanah.v14i1.1049. 
dipertentangkan, sebab keduanya berada dalam satu konsep perjuangan. ${ }^{7}$ Islam adalah nilai-nilai luhur yang bersifat universal, sedangkan keindonesiaan adalah realitas sosial yang harus diisi dengan nilai-nilai itu tanpa harus menafikannya. Nilainilai Islam harus hadir dalam kebudayaan dan kebhinekaan yang sudah mengakar kuat dalam jati diri dan memori kolektif bangsa Indonesia. Sebagaimana Islam datang ke bumi Nusantara melalui para pendakwah yang bersifat toleran dan damai.

Berdasarkan latar belakang tersebut, maka tujuan dalam penelitian ini perlu menelaah kembali tentang pemikiran KH. Hasyim Asy'ari mengenai keislaman dan kebangsaan. Karena saat ini masih ada kelompok-kelompok tertentu yang ingin memisahkan antara keislaman dan kebangsaan yang mengkhawatirkan dapat memicu pecah belahnya umat. Dengan demikian, pemikiran KH. Hasyim Asy'ari dalam artikel ini dapat dijadikan refleksi kita semua dan khazanah pembelajaran bagi bangsa. Dalam artikel ini membahas biografi KH. Hasyim Asy'ari dan pemikirannya tentang keislaman dan kebangsaan.

\section{Metode}

Metode yang digunakan dalam penelitian ini adalah metode kepustakaan (library research). Metode ini merupakan metode pengumpulan data dengan cara memahami dan mempelajari teori-teori dari berbagai literatur yang berhubungan dengan penelitian. Menurut Mestika Zed ada empat tahap metode kepustakaan yaitu menyiapkan perlengkapan alat yang diperlukan, menyiapkan bibliografi kerja, mengorganisasikan waktu dan membaca serta mencatat bahan penelitian. ${ }^{8}$

Pengumpulan data dengan cara mencari dan merekonstruksi dari berbagai sumber seperti buku, arsip, majalah, dokumen-dokumen tua, jurnal, dokumentasi, surat-surat kabar dan lain-lain yang berkaitan dengan pemikiran KH. Hasyim Asy'ari. ${ }^{9}$ Metode analisis menggunakan analisis konten dan analisis deskriptif. Bahan kepustakaan yang didapat dari berbagai referensi dianalisis secara kritis dan mendalam agar dapat mendukung proposisi dan gagasan penelitian. Dalam penelitian kepustakaan ini peneliti memperhatikan langkah-langkah dalam meneliti kepustakaan, memperhatikan metode penelitian dalam rangka mengumpulkan data, membaca dan mengolah bahan pustaka serta peralatan yang harus dipersiapkan dalam penelitian tersebut, kegunaannya mempermudah peneliti dalam mendapatkan data. ${ }^{10}$

${ }^{7}$ Rofiq Nurhadi, 'Pendidikan Nasionalisme-Agamis dalam Pandangan K.H. Ahmad Dahlan dan K.H. Hasyim Asyfari', CAKRAW ALA: Jurnal Studi Islam 12, no. 2 (Desember 2017): 121-132, https://doi.org/10.31603/cakrawala.v12i2.1716.

${ }^{8}$ Mestika Zed, Metode Penelitian Kepustakaaan (Jakarta: Yayasan Pustaka Obor Indonesia, 2004), 14.

${ }^{9}$ Bungaran Anthonius Simandjuntak and Soedjito Sosrodihardjo, Metode Penelitian Sosial (Edisi Revisi) (Jakarta: Yayasan Pustaka Obor Indonesia, 2014).

${ }^{10}$ I Komang Rupadha, 'Memahami Metode Analisis Pasangan Bibliografi (Bibliographic Coupling) dan Ko-Sitasi (Co-Citation) serta Manfaatnya untuk Penelitian Kepustakaan', Lentera Pustaka: Jurnal Kajian Ilmu Perpustakaan, Informasi dan Kearsipan 2, no. 1 (Oktober 2016): 68-78, https://doi.org/10.14710/lenpust.v2i1.12358. 


\section{Pembahasan}

\section{Biografi KH. Hasyim Asy'ari}

Kehidupan KH. Hasyim Asy'ari bisa diungkapkan dengan kata-kata yang sederhana, "dari pesantren kembali ke pesantren”, sebab ia dibesarkan di lingkungan pesantren. Setelah tujuh tahun lamanya di Mekkah melakukan ibadah haji dan belajar di lingkungan seperti pesantren, yaitu Masjidil Haram (Mekkah) dan Masjid Nabawi (Madinah). Ia kembali ke Nusantara (Indonesia) untuk mendirikan pesantren sendiri dan menghabiskan sebagian besar waktunya, digunakan untuk mengajar para santrinya di pesantren. Ia bahkah mengatur "kegiatan-kegiatan politik" dari pesantren.

Melihat dari latar belakang keluarga, KH. Hasyim Asy’ari diberi nama lengkap oleh orang tuanya adalah Muhammad Hasyim Asy'ari. Ia lahir dari kalangan elit kyai Jawa pada 24 Dzulqa'dah 1287 atau 14 Februari 1871 di desa Gedang sekitar dua kilometer sebelah timur kabupaten Jombang. ${ }^{11}$ Ia wafat di Jombang pada 7 Ramadhan 1366 H/25 Juli 1947 M sebab terkena tekanan darah tinggi. ${ }^{12}$ Ayahnya bernama Asy'ari, ia adalah pendiri pesantren Keras di Jombang, sementara kakeknya, Kyai Usman, adalah kyai terkenal dan pendiri pesantren Gedang yang didirikan pada akhir abad ke-19. ${ }^{13}$ Moyang Hasyim Asy'ari bernama Kyai Sihah, adalah pendiri pesantren Tambakberas, Jombang. ${ }^{14}$

KH. Hasyim Asy'ari adalah putra ketiga dari 11 bersaudara. Ayahnya adalah Kyai Asy'ari asal Demak. Ibunya, Nyai Halimah, adalah putri Kyai Usman. Sang ibu merupakan anak pertama dan tiga laki-laki dan dua perempuan. Dari pernikahan Kyai Asy'ari dan Nyai Halimah, lahirlah Hasyim Asy'ari. Ia mempunyai 10 saudara, yaitu Nafi'ah, Ahmad Saleh, Radjah, Hasan, Anis, Fathanah, Maimunah, Maksum, Nahrawi, dan Adnan. ${ }^{15}$ Secara geneologi KH. Muhammad Hasyim Asy'ari bin Asy'ari bin Abdul Wahid bin Abdul Halim, yang memiliki gelar pangeran Bona, bin Abdul Rohman Rahman, yang dikenal dengan Jaka Tìngkir Sultan Hadiwijoyo, bin Abdullah bin Abdul Aziz bin Abdul Fatih bin Maulana Ishaq, dan Raden 'Ain AlYaqin yang disebut dengan Sunan Giri. Dengan demikian, dipercayai bahwa keluarganya adalah keturunban raja muslim jawa, Jaka Tingkir, dan raja Hindu Majapahit, Brawijaya VI, sehingga bisa dikatakan keturunan KH. Hasyim Asy'ari berasal dari keluarga bangsawan. ${ }^{16}$

\footnotetext{
${ }^{11}$ Lathiful Khuluq, 'K.H. Hasyim Asy'ari's Contribution to Indonesian Independence', Studia Islamika 5, no. 1 (April 1998): 46, https://doi.org/10.15408/sdi.v5i1.760.

${ }^{12}$ Hartono Margono, 'KH. Hasyim Asy'ari dan Nahdlatul Ulama: Perkembangan Awal dan Kontemporer' 26, no. 3 (Juli 2011): 341.

${ }^{13}$ Lathiful Khuluq, Fajar kebangunan ulama: biografi K.H. Hasyim Asy'ari, Cet. VI (Yogyakarta: LKiS, 2013), 17. 2006), 31 .

${ }^{14}$ Mohammad Herry, Tokoh-Tokoh Islam Yang Berpengaruh Abad 20 Jakarta: Gema Insani,

15Zuhairi Misrawi, Hadratussyaikh Hasyim Asy'ari: Moderasi, Keumatan, Dan Kebangsaan (Jakarta: Penerbit Buku Kompas, 2010), 26.

${ }^{16}$ Muhamad Rifai, K.H. Hasyim Asy'ari: Biografi Singkeat, 1871-1947, Cet. 1 (Yogyakarta: Garasi : Didistribusikan oleh ar-Ruzz Media, 2009).
} 
Riwayat pendidikan Pendidikan KH. Hasyim Asy'ari lebih banyak diperoleh dari lingkungan pesantren, khususnya dari lingkungan keluarganya yang dikenal sebagai pendidik di pesantren. Pada umur lima tahun, KH. Hasyim Asy'ari dalam asuhan orang tua dan kakeknya di pesantren Gedang. Di pesantren ini, para santri mengamalkan ajaran agama Islam dan belajar berbagai cabang ilmu agama Islam. Suasana tersebut mempengaruhi karakter Hasyim Asy'ari yang sederhana dan rajin belajar. Pada 1876, ketika Hasyim Asy'ari berumur enam tahun, ayahnya mendirikan pesantren Keras, sebelah Selatan Jombang. ${ }^{17}$ Kehidupan masa kecilnya di lingkungan pesantren ini memang berperan besar dalam mempengaruhi pembentukan wataknya yang tekun mencari ilmu pengetahuan dan kepeduliannya pada pelaksanaan ajaranajaran agama dengan baik. ${ }^{18}$

KH. Hasyim Asy'ari mendapat pendidikan langsung dari ayah dan kakeknya, kyai Usman. Hasratnya yang besar untuk menuntut ilmu mendorongnya belajar lebih giat dan rajin. Beliau termasuk anak yang mudah menyerap dan menghafal ilmu yang diberikan. Keistimewaan beliau dalam menyerap dan menghafal ilmu, menjadikannya diberi kesempatan oleh ayahnya pada usia masih remaja, 13-14 tahun, untuk membantu mengajar di pesantren. ${ }^{19}$ Setelah itu pada usia 15 tahun, KH. Hasyim Asy'ari mulai mengembara ke berbagai pesantren di pulau Jawa untuk memperdalam ilmu agama, seperti di pesantren Wonocolo Jombang, pesantren di Purbolinggo, pesantren Langitan, pesantren Tranggilis, dan berguru kepada Kyai Kholil di Bangkalan Madura.

Setelah memperoleh bekal pendidikan dari lingkungan pesantren, $\mathrm{KH}$. Hasyim Asy'ari melanjutkan pendidikannya di kota suci Mekkah, bersamaan dengan pelaksanaan ibadah haji. Ketika selesai menunaikan ibadah haji, Kyai Hasyim tidak langsung kembali ke Tanah Air. Tetapi ia menetap beberapa bulan untuk mendalami ilmu-ilmu keagamaan, terutama ilmu hadis yang merupakan salah satu bidang ilmu yang paling digemarinya. Hal itu bisa dilihat, karya-karya yang ditulis $\mathrm{KH}$. Hasyim Asy'ari selama hidupnya merupakan pembahasan yang berisi tentang hadis-hadis. ${ }^{20}$

KH. Hasyim Asy'ari selama belajar mendalami ilmu keagamaannya di Mekkah, ia berguru kepada ulama-ulama besar internasional dan ada juga yang dari Indonesia, seperti Syaikh Syatha, Syaikh Dagistany, Syaikh Al-Allamah Abdul Hamid Al-Darustany, dan Syaikh Muhammad Syuaib Al-Maghriby, sedangkan yang dari Indonesia ada Syaikh Mahfudz Termas, Syaikh Mahmud Khatib Al-Minangkabawy, Imam Nawawi Al-Bantany dan ulama-ulama besar lainnya. ${ }^{21}$ Dengan demikian, guruguru beliau tersebut telah mewarnai corak tentang pemahaman atau pemikiran

${ }^{17}$ Muhammad Rijal Fadli dan Bobi Hidayat, KH. Hasyim Asy'ari Dan Resolusi Jihad Dalam Usaba Mempertabankan Memerdekaan Indonesia (Metro, Lampung: Laduny Alifatama, 2018), 47.

${ }^{18}$ Rifai, K.H. Hasyim Asy'ari Biografi Singkat 1871-1947, 21.

${ }^{19}$ Margono, 'KH. Hasyim Asy'ari dan Nahdlatul Ulama: Perkembangan Awal dan Kontemporer', 337.

${ }^{20}$ Misrawi, Hadratussyaikh Hasyim Asy'ari Moderasi, Keumatan, Dan Kebangsaan, 44.

${ }^{21}$ Syamsul A'dlom, "Kiprah KH. Hasyim Asy'ari dalam Mengembangkan Pendidikan Agama Islam," JURNAL PUSAKA 2, no. 1 (February 2014): 14.

Khazanah, Vol. 18 (1), 2020 
mengenai keislaman dalam setiap mengambil sikap dan pandangan terhadap suatu masalah yang dihadapinya.

KH. Hasyim Asy'ari selama hidupnya berada dalam lingkungan pendidikan Islam, baik selama di tanah air, maupun di tanah suci Mekkah. Lingkungan inilah yang telah mempengaruhi terhadap tradisi keilmuan yang berlaku di pesantren menjadi bagian dari pemikiran-pemikiran dalam pendidikan Islam. KH. Hasyim Asy'ari juga mengadopsi pendidikan Islam klasik yang lebih mengedepankan aspekaspek normatif, tradisi belajar-mengajar, dan etika dalam belajar yang dipandangnya akan mengantarkan umat Islam kepada zaman keemasan.

\section{Pemikiran Keislaman KH. Hasyim Asy'ari}

KH. Hasyim Asy'ari merupakan seorang penulis yang produktif. Sebagian besar ia menulis dalam bahasa Arab, tema-tema yang dibahas dari berbagai bidang seperti tasawuf, fiqh dan hadis. Sampai sekarang pun kitab-kitab yang ditulisnya masih dipelajari di berbagai pesantren. Diantara tulisannya adalah At-Tibyan in Nabi'an Muqatha'atil Arbam wal Aqarib wal Akhawan (Penjelasan mengenai larangan memutuskan hubungan kerabat dan persahabatan), Adabul 'Alim wal Muta'alim (Etika guru dan murid) mengenai etika belajar dan urgensi ilmu pengetahuan, Al-Risalah AlJami'ah (kitab lengkap) menjelaskan berbagai topik seperti kematian dan hari kebangkitan, arti sunnah dan bidah, Al-Qanun al-Asasi li Jam'iyah Nabdlah al-Ulama (Aturandasar perkumpulan Nahdlatul Ulama) membicarakan prinsip-prinsip utama organisasi NU, Al-Mawa'iz. (Nasihat) mengajak umat muslim untuk bersatu dan bekerja sama, Hadits al-Mawt wa Ashrah al-Sa'ah (Hadits mengenai kematian dan kiamat) ${ }^{22}$, Al-Durar Al-Muntathirah fit Tis' 'Asyarah (Mutiara-mutiara mengenai sembilan belas masalah) mengenai tasawuf, Al-Risalah At-Taubidiyyah (Catatan tentang teologi) mengenai Ablussunah Wal Jama'ah dan sebagainya. Sebenarnya karya-karya $\mathrm{KH}$. Hasyim Asy'ari masih banyak selain yang tertulis di atas, bahkan pidato-pidato KH. Hasyim Asy'ari pun banyak yang diterbitkan dalam surat kabar. ${ }^{23}$

Pemikiran keislaman KH. Hasyim Asy'ari terbagi di beberapa bidang ilmu Islam seperti tasawuf, teologi dan fikih. Dalam pemikiran keislaman, KH. Hasyim Asy'ari menggunakan corak Islam tradisional, corak Islam tradisonal dipandang sebagai ajaran yang telah diajarkan oleh pendahulu yaitu walisongo. Ia tetap mempertahankan corak Islam tradisional ini, sebab paham ini sudah mulai tergerus oleh paham-paham modernis. Oleh karena itu, dalam pemikiran-pemikiran KH. Hasyim Asy'ari bercorak pada Islam tradisional yang sangat berbeda dengan pahampaham modernis, sampai karya-karya yang ditulisnya beranut pada paham Islam tradisional.

${ }^{22}$ Lathiful Khuluq, Tafsir Pemikiran Kebangsaan Dan Keislaman Hadratussyaikh K.H. M. Hasyim Asy'ari (Jombang, Jawa Timur: Penerbit dan distribusi, Penerbit Tebuireng, 2018), 55.

${ }^{23}$ Muhammad Isham Hadziq (ed), At-Ta'rif Bi al-Muallif. Dalam Hasyim Asy'ari, Adab al-Alim Wa al-Muta'allim (Jombang: Maktabat al-Turats al-Islami, 1995), 145. 


\section{Tasawuf (Sufisme)}

Pemikiran KH. Hasyim Asy'ari mengenai tasawuf (sufisme) dijelaskan dalam karyanya yaitu kitab berjudul Ad-Durar Al-Muntatbirah fil Masa'il At-Tis' Asyarah (mutiara-mutiara tercecer tentang sembilan belas masalah) dan kitab At-Tibyan fin Nabi'an Muqatha'atil Arbam wal Aqarib wal Akhawan (penjelasan mengenai larangan memutuskan kerabat dan teman). Dalam tulisannya beliau ini mengecam keras terhadap penyimpangan-penyimpangan ajaran sufi.

Contohnya dalam kitab Ad-Durar, KH. Hasyim Asy'ari menjelaskan bahwa dalam penyimpangan ajaran sufi adalah "para sufi itu sendri". Maka KH. Hasyim Asy'ari membuat terobasan hal-hal yang menyimpang itu untuk dilakukan dengan perilaku yang biasa saja (tawasuth/moderat) jangan terlalu berlebihan. ${ }^{24}$ Seperti dalam memuliakan guru, ia memberikan contoh terhadap santri-santrinya kalau dirinya tidak bersedia dipanggil sebagai guru sufi, jadi harus bersikap sederhana/biasa saja bahkan ia melarang santrinya untuk mengikuti persaudaraan sufi, semuanya dilakukan bermaksud supaya tidak meninggalkan pelajaran. ${ }^{25}$ Konsep ajaran sufi yang dituliskan KH. Hasyim Asy'ari telah mengajarkan bahwa dalam ajaran sufi tidak boleh berlebihlebihan terhadap apapun, tetapi ia menganjurkan untuk biasa-biasa saja, tujuannya supaya sufisme dalam Islam tidak dianggap radikal. ${ }^{26}$

Pemikiran tasawuf (sufi) KH. Hasyim Asy'ari bertujuan untuk memperbaiki perilaku umat Islam secara umum dan dalam banyak hal, ini semua merupakan perulangan prinsip-prinsip sufisme yang telah diajarkan oleh Imam Al-Ghazali (ibya' ulumuddin). Menurut KH. Hasyim Asy'ari dan Madjid ada empat peraturan yang harus dilakukan jika seseorang ingin disebut sebagai pengikut suatu tarekat (bagian dari ilmu sufisme), yaitu 1) Menghindari penguasa yang tidak melaksanakan keadilan; 2) Menghormati mereka yang berusaha dengan sungguh-sungguh meraih kebahagiaan di akhirat; 3) Menolong orang miskin dan 4) Melaksanakan shalat berjama'ah. ${ }^{27}$

Pemikiran sufistik KH. Hasyim Asy'ari sesuai dengan prinsip-prinsip ajaran Islam (orthodox) dan sangat berbeda dengan sufisme yang dikembangkan oleh Hamzah Fansuri, Abd Rauf As-Sinkili dan Syamsudin As-Sumatrani di Nusantara abad ke 13 M. Menurut Fazlur Rahman, Sufi Islam murni ini berkembang setelah adanya gerakan pembaruan neo-sufi yang berpusat di Mekkah dan Madinah pada akhir abad $19 \mathrm{M}$, bertujuan membersihkan sufisme dari ajaran-ajaran asketik dan metafisik untuk digantikan dengan ajaran-ajaran Islam murni dalam sufisme.

${ }^{24}$ Khuluq, Tafsir Pemikiran Kebangsaan Dan Keislaman Hadratussyaikh K.H. M. Hasyim Asy'ari, 68.

${ }^{25}$ Akarhanaf, Kiai Hasjim Asj'ari Bapak Umat Islam Indonesia (Jombang: Pesantren Tebuireng, 1950), 41.

${ }^{26}$ Kambali Zutas, "Literacy Tradition in Islamic Education in Colonial Period (Sheikh Nawawi al Bantani, Kiai Sholeh Darat, and KH Hasyim Asy'ari)," Al-Hayat 1, no. 1 (Oktober 2017): 16-31, https://alhayat.or.id/index.php/alhayat/article/view/2.

${ }^{27}$ Nurcholis Madjid, Islam, Iman Dan Ibsan Sebagai Trilogi Ajaran Islam (Jakarta: Yayasan Paramadina, 1994).

Khazanah, Vol. 18 (1), 2020 
Pembaruan dalam ajaran sufi ini telah diterima oleh KH. Hasyim Asy'ari ketika belajar di Hijaz pada akhir abad 19 M. $^{28}$

KH. Hasyim Asy'ari telah mendasarkan pemikiran sufismenya kepada ajaran sufi Islam murni yang diformulasikan dan dipraktikan oleh Al-Junaidi Al-Baghdadi dan Imam Al-Ghazali. Berbeda dengan muslim modernis yang cenderung menolak segala jenis praktik sufisme yang dianggap menyimpang dari kemurnian Islam, sebab membuat bid'ah dalam ibadah dan mendorong kepada kemusyrikan. Sedangkan muslim tradisional menganggap sebagian persaudaraan sufi masih dalam bingkai Islam, artinya membolehkan jenis praktik sufisme. ${ }^{29}$ Persaudaraan-persaudaraan sufi ini diakui dalam struktur organisasi Nahdlatul Ulama sebagai badan otonom dalam At-Tariqat Al-Mu'tabarah Al-Nabdliyah (Persaudaraan sufi Nahdlatul Ulama yang lurus), badan ini sebagian besar terdiri atas sufi Qadariyah dan Naqshabandiyah. Menurut Bruinessen, kebanyakan pesantren di Jawa telah mengembangkan Islam murni selama berabad-abad dan menghindari paham sufi yang sesat. Bahkan pesantren-pesantren di Jawa ini merupakan pusat dari pengembangan Islam murni sampai saat ini, sedangkan di luar Jawa, doktrin-doktrin sufi spekulatif masih berkembang. ${ }^{30}$

Berdasarkan uraian di atas, pemikiran KH. Hasyim Asy'ari di bidang tasawuf mengikuti sufi ortodoks yang telah dirumuskan oleh Imam Junaidi Al-Baghdadi dan Imam Al-Ghazali. Jenis sufi ini penekanannya terhadap peningkatan nilai-nilai moral dan kesalehan dengan jalan melaksanakan ajaran-ajaran yang dibawa Nabi Muhammad Saw. Sufi yang diajarkan beliau bukanlah yang menjurus ke panteistik dan syirik melainkan sesuai dengan ajaran-ajaran Islam Sunni. KH. Hasyim Asy'ari juga mencoba untuk mengurangi akibat negatif dari praktik sufi dengan menekankan adanya persayaratan-persayaratan tertentu bagi orang yang ingin mempraktikan ajaran sufi.

\section{Teologi (Tauhid) dan Ablus Sunnab wal Jama'ab}

Dalam pemikiran teologi KH. Hasyim Asy'ari menulis kitab mengenai ablus sunnah wal jama'ah bertajuk Ar-Risalah At-taubidiyyah (tentang teologi) dan Al-Qala'id fi Bayani ma Yajib minal 'Aqa'id (mengenai kewajiban-kewajiban menurut akidah yang dijelaskan dalam syair-syair). KH. Hasyim Asy'ari menjelaskan bahwa dalam meyakini keesaan Tuhan ada tiga tingkatan, Pertama, pujian terhadap keesaan Tuhan (biasanya ini yang dimiliki orang-orang awam). Kedua, meliputi pengetahuan dan pengertian mengenai Tuhan (dimiliki oleh ulama biasa/ablu zabir). Ketiga, tumbuh dari perasaan

\footnotetext{
${ }^{28}$ Fazlur Rahman (ed), "Revival and Reform in Islam. In Cambridge History of Islam," vol. 2 (Cambridge: Cambridge University Press, 1970).

${ }^{29}$ Abdullah Hakam, 'KH. Hasyim Asy'ari Dan Urgensi Riyadah Dalam Tasawuf Akhlaqi', Teosofi: Jurnal Tasawnf Dan Pemikiran Islam 4, no. 1 (June 2014): 149, https://doi.org/10.15642/teosofi.2014.4.1.145-166.

${ }^{30}$ Martien Van Bruinessen, Kitab Kuning, Pesantren Dan Tarekat (Bandung: Mizan, 1995).
} 
terdalam (hanya bisa dimiliki oleh para sufi yang tingkatannya sampai ke pengetahuan pada Tuhan/ma'rifah dan mengetahui esensi tuhan/haqiqab). ${ }^{31}$

Tentang paham ini KH. Hasyim Asy'ari mengutip sabda Nabi Saw, bahwa iman adalah perbuatan yang paling dicintai Tuhan dan menyekutukan Tuhan hal yang dibenci. Menjelaskan juga dari beberapa ulama, bahwa percaya kepada keesaan Tuhan membutuhkan iman dan siapa saja tidak memiliki iman tidak akan percaya kepada keesaan Tuhan. Oleh sebab itu, KH. Hasyim Asy'ari mencela paham Komunisme dalam pidato Muktamar NU ke-17 24 Mei 1947 yang intinya "ia sangat khawatir atas kepercayaan paham Komunis akan membahayakan generasi penerus bila tertanam, karena dapat merusak kepercayaan mereka pada Islam itu sendiri', sehingga bagi KH. Hasyim Asy'ari, Islam tidak saja berusaha membebaskan manusia dari menyembah lebih dari satu Tuhan dan membimbing mereka untuk menyembah satu Tuhan (Tauhid), tetapi memajukan juga dalam aspek sosial, politik dan ekonomi masyarakat terbelakang. Selain itu, Islam juga berusaha memupuk semangat persaudaraan Islam dengan menghilangkan perbedaan yang disebabkan oleh keturunan, posisi kekayaan atau kebangsaan. ${ }^{32}$ Ia juga menjelaskan tentang persaudaraan Islam merupakan dasar dari demokrasi yang sangat menghargai kemanusiaan hal ini telah diperkenalkan sejak awal perkembangan Islam. Dengan menjaga persaudaraan Islam (Ukhwab Islamiyah), ketidakadilan akan menghilang dari masyarakat. ${ }^{33}$

Sejalan dengan ide-ide teologi KH. Hasyim Asy'ari, Achmad Shiddiq (1979) mengatakan bahwa dalam akidah muslim harus menerapkan konsep tawassut (moderat), artinya keseimbangan antara penggunaan pemikiran rasional dan dalil-dalil teks al-Qur'an dan as-Sunnah. Keseimbangan ini dapat dicapai dengan menjaga keaslian doktrin Islam dari pengaruh-pengaruh luar dan menghindari dari mencap/melabeli muslim lain sebagai kafir atau sebagainya, walaupun mereka belum memurnikan kepercayaannya. Dengan begitu, keseimbangan antara iman dengan pikiran merupakan bagian yang tidak bisa dipisahkan dari dasar-dasar ajaran Islam (ushuluddin). ${ }^{34}$

Pemikiran teologi KH. Hasyim Asy'ari tersebut sejalan dengan pemikiran tradisional berdasarkan formulasinya Abu Hasan Al-Asy'ari dan Abu Mansur AlMaturidi. ${ }^{35}$ Maka, formulasi ini bagian dari Sunisme yang berusaha menjembatani antara mereka yang mendukung kebebasan berkehendak dan yang berpedoman pada

\footnotetext{
${ }^{31}$ Muhaemin, 'Teologi Aswaja Nahdhatul Ulama Di Era Modern: Studi Atas Pemikiran Kyai Hasyim Asy'ari', Jurnal Diskursus Islam 1, no. 2 (January 2013): 319, https://doi.org/10.24252/jdi.v1i2.6634.

${ }^{32}$ Khuluq, Tafsir Pemikiran Kebangsaan Dan Keislaman Hadratussyaikh K.H. M. Hasyim Asy'ari, 60.

${ }^{33}$ Budi Harianto, 'Relasi Teologi Aswaja Dengan Ham Perspektif Kiai Said Aqil Siroj', HUMANISTIKA: Jurnal Keislaman 4, no. 2 (November 2019): 138, https://doi.org/10.36835/humanistika.v4i2.34.

${ }^{34}$ Achmad Shiddiq, Khithttah Nadliyah (Surabaya: Balai Buku, 1979), 41.

35Zainal Arifin and Muhammad Fathoni, "Jejak Pemikiran Syaikh Nawawi Al-Banteni Terhadap Pemikiran Teologi, Fiqih Dan Tasawuf Hadratusy Syaikh KH. Hasyim Asy'ari," Al Qodiri: Journal of Education, Social and Religious 16, no. 1 (April 2019): 46-56, https://doi.org/10.1234/al\%20qodiri.v16i1.3313.
} 
fatalisme, sehingga teologi Al-Asy'ari ini dapat dianggap sebagai sintesis diantara berbagai sekte-sekte teologi. ${ }^{36}$ Lagi pula, dengan mendasarkan pada kombinasi pikiran dan wahyu dalam menyelesaikan masalah-masalah teologi, paham Asy'ariyah telah menyelamatkannya dari ancaman Hellenisasi. ${ }^{37}$

Menurut KH. Hasyim Asy'ari ablussunnab wal jama'ah adalah ulama dalam bidang tafsir Al-qur'an, Sunnah Rasul, dan fiqh yang tunduk pada tradisi Rasul dan Khulafaur Rasyidin. ${ }^{38} \mathrm{KH}$. Hasyim Asy'ari selanjutnya menyatakan bahwa sampai sekarang ulama tersebut yang mengikuti empat mazhab Hanafi, Maliki, Syafi'i dan Hanbali. Paham ini diterapkan dalam ormas NU yang menyatakan sebagai pengikut, penjaga dan penyebar ablussunab wal jama'ah. ${ }^{39} \mathrm{NU}$ menerima paham ini karena sesuai dengan tujuan-tujuan NU sendiri khususnya berkaitan dengan membangun hubungan ulama Indonesia, yaitu mengikut salah satu dari empat mazhab Sunni dan menjaga kurikulum pesantren agar sesuai dengan prinsip-prinsip ablussunah wal jama'ah, yang berarti mengikuti ajaran Nabi Muhammad Saw dan kesepakatan para ulama. Menurut Michael Laffan, ablussunah wal jama'ab itu muslim yang konsisten dan dengan kuat berpegang teguh pada Sunnah Nabi dan jalan hidup dari para Sahabat di bidang doktrin, praktik, dan etika. Semua organisasi Islam selain NU dapat disebut ablussunah wal jama'ah, apabila mereka memenuhi kriteria tersebut. Maka, apabila tidak sejalan dengan doktrin ini hal tersebut dianggap tidak sesuai dengan prinsip-prinsip ablussunab wal jama'ab. ${ }^{40}$

Pada dasarnya dalam pemikiran KH. Hasyim Asy'ari menggunakan istilah ablussunah wal jama'ah digunakan untuk melindungi dari gerakan-gerakan pembaruan yang dilancarkan oleh muslim modernis. Namun, tidaklah semena-mena menentang pembaruan, bahkan selalu berusaha menghilangkan penyimpangan dan keraguan dalam memahami al-Qur'an dan Sunnah Rasul. ${ }^{41}$ Selain itu, gerakan ini bukan sebagai reaksi atas sekte-sekte sesat seperti Syiah, Khawarij dan Muktazilah, melainkan sudah ada sejak era Nabi Muhammad Saw. Dalam kenyataannya, ada tiga ciri perilaku dan kepercayaan ablussunnah wal jama'ah pada saat itu bahkah masih ada sampai saat ini: Pertama, at-tawasut yang berarti moderat. Artinya seorang muslim harus berbuat secara moderat/ambil jalan tengah dalam kehidupan. Kedua, al-itidal berarti tegak lurus.

${ }^{36}$ Ahmad Najib Burhani, “Al-Tawassut Wal-I'tidal: The NU and Moderatism in Indonesia Islam', Asian Journal of Social Science 40, no. 5 (November 2012): 567, https://doi.org/10.1163/15685314-12341262.

${ }^{37}$ N.U (Organisasi), Aswaja An-Nabdliyah: Ajaran Ablussunab Wal Jama'ah Yang Berlaku Di Lingkungan Nabdlatul Ulama (Surabaya: Khalista, 2007), 13.

${ }^{38}$ Asmani Jamal Ma'aruf (ed), Pemikiran KH. Hasyim Asy'ari Tentang Agama, Perempuan Dan Kemasayarakatan (Yogyakarta: Aswaja Pressindo, 2018).

${ }^{39}$ Ahmad Choirul Rofiq, 'Argumentasi Hasyim Asy'ari Dalam Penetapan Ahlus Sunnah Wal Jama'ah Sebagai Teologi Nahdlatul Ulama', Jurnal Kontemplasi 5, no. 1 (Agustus 2017): 40, https://doi.org/10.21274/kontem.2017.5.1.

${ }^{40}$ Michael Laffan, 'The Fatwa Debated ? Shura in One Indonesia Context," Islamic Law and Society', Islamic Law and Society 12, no. 1 (June 2005): 18, https://doi.org/10.1525/sp.2007.54.

${ }^{41}$ Fauzan Saleh, 'The School of Ahl Al-Sunnah Wa Al-Jama'ah And The Attachment of Indonesian Muslims to Its Doctrines', Journal of Indonesian Islam 2, no. 1 (June 2008): 30, https://doi.org/10.15642/JIIS.2008.2.1. 
Maksudnya menjadi seorang muslim harus menegakkan keadilan atau menegakkan kebenaran dalam kehidupannya. Ketiga, at-tawazun berarti seimbang. Artinya seorang muslim harus menunjukkan keseimbangan dalam perbuatannya. ${ }^{42}$

Dengan demikian, dalam teologi, KH. Hasyim Asy'ari berpegang pada formulasinya Al-Asy'ari dan Al-Maturidi yang menurutnya dianggap teologi terbaik. Seorang muslim yang memahami pemikiran KH. Hasyim Asy'ari tentang teologi juga akan menggunakan formulasi teologi yang sama dengan KH. Hasyim Asy'ari sebagaimana kaum muslimin yang tergabung dalam organisasi NU, yang selalu berpegang teguh pada pemikiran KH. Hasyim Asy'ari. Selanjutnya, istilah ablussunah wal jama'ah KH. Hasyim Asy'ari telah mempercayai kebenaran doktrin ini dengan prinsip mengikuti jalan Nabi Muhammad Saw dan Khulafaur Rasyidin sebagaimana yang dijalankan oleh empat Mazhab Sunni. Oleh karena itu KH. Hasyim Asy'ari mengikuti tradisi Sunni.

\section{Fiqh}

Pemikiran KH. Hasyim Asy'ari tentang fiqh yang paling menonjol adalah tentang ijtihad dan taqlid, menurutnya hal yang sangat penting yaitu mengikuti salah satu dari empat mazhab sunni (mazabib). KH. Hasyim Asy'ari menjelaskan tentang ini dan hal-hal lainnya di dalam Muqaddimat al-Qanun al-Asasi al-Nabdlah al-Ulama (pengantar terhadap aturan-aturan dasar Nahdlatul Ulama), menurut Bruinessen (1999) kitab ini merupakan hasil dari ijtihad KH. Hasyim Asy'ari bersama ulama lainnya, yang berdasarkan Al-qur'an dan Sunnah Rasul. ${ }^{43}$

Ijtihad disini merupakan sarana paling efektif untuk mendukung tetap tegak dan eksistensinya hukum Islam serta menjadikan sebagai tatanan hidup yang up to date agar dapat menjawab tantangan zaman. ${ }^{44}$ Sedangkan taqlid adalah mengikuti pendapat orang lain tanpa mengetahui sumber atau alasannya. Seperti seseorang telah mengikuti pendapat Imam Syafi'i tanpa mengetahui dalilnya atau hujjahnya, orang seperti ini disebut Muqallid. ${ }^{45}$ Keduanya ini harus berkaitan, taqlid untuk mengisi kekosongan ketika j̈tibad tidak bisa diterapkan. Kalau tidak, itu akan menjadi beban yang tidak semestinya untuk meminta semua orang menjadi seorang mujtabid (orang yang melakukan ijtihad). ${ }^{46}$

Dengan demikian, taqlid disini awalnya dilarang, menjadi boleh apabila seseorang tidak mampu untuk berijtihad dan menggunakan potensi akalnya dalam memahami nash-nash Al-qur'an dan As-Sunnah. Hal ini sejalan dengan pemikiran KH. Hasyim Asy'ari mengenai larangan taqlid hanya ditujukan kepada seseorang yang

${ }^{42}$ Khuluq, Tafsir Pemikiran Kebangsaan Dan Keislaman Hadratussyaikh K.H. M. Hasyim Asy'ari, 67. LKiS), 37.

${ }^{43}$ Martin Van Bruinessen, NU, Tradisi, Relasi-Relasi Kuasa, Pencarian Wacana Baru (Yogyakarta:

${ }^{44}$ Mudrik Al-Farizi, 'Ijtihad, Taqlid Dan Talfiq', Al-Mabsut Jurnal Studi Islam Dan Sosial 8, no. 1 (April 2014): 215.

${ }^{45}$ Abdurrahman Misno, 'Redefinisi Ijtihad Dan Taklid', Al-Mashlahah Jurnal Hukum Dan Pranata Sosial Islam 2, no. 4 (Desember 2014): 19, https://doi.org/10.30868/am.v2i04.133.

${ }^{46}$ Mohamed A. Abdelaal, 'Taqlīd V. Ijtihād: The Rise Of Taqlid As The Secondary Judicial Approach In Islamic Jurisprudence', The Journal Jurisprudence 5, no. 4 (2012).

Khazanah, Vol. 18 (1), 2020 
mampu melakukan ijtihad, meskipun kemampuannya hanya pada satu bidang, sehingga KH. Hasyim Asy'ari berpendapat bagi siapa saja yang tidak mampu melakukan ijtihad maka harus mengikuti salah satu dari empat mazhab. Sebaliknya jika para mujtabid dilarang bertaqlid pada hasil ijtibad hukum orang lain.

Pendapat tersebut dipegang oleh organisasi NU yang terus menekankan bahwa persyaratan melakukan ijtihad tidaklah sederhana. Meskipun demikian, NU menganjurkan para anggotanya untuk meningkatkan pengetahuan agama mereka agar meningkat dari status taqlidnya. Organisasi NU menganggap bahwa untuk orang biasa yang tidak mampu melakukan ijtibad, diperbolehkan bertaqlid pada salah satu dari empat mazhab Sunni (Hanafi, Maliki, Syafi'i dan Hanbali) sebab, sebagaimana yang disabdakan Rasul bahwa perbedaan pendapat di kalangan masyarakat muslim adalah rahmat dan memaksakan suatu pendapat dibenci Tuhan.

KH. Hasyim Asy'ari menjelaskan bahwa mengikuti salah satu empat mazhab Sunni itu bermanfaat bagi umat Islam, karena setiap generasi ulama mengambil manfaat dan mengembangkan pemahaman keislamannya dari usaha generasi pendahulunya. Seperti para tabi'in bersandar kepada para sahabat, sementara para tabi'at tabiin bersandar kepada tabi'in dan seterusnya. Oleh karena itu, penyandaran terus menerus dan penerimaan ilmu pengetahuan dan generasi pendahulu ini merupakan sumber informasi yang tak habis-habisnya bagi para ilmuwan muslim. Hal ini terutama mengingat ajaran Islam tidak dapat dipahami kecuali dengan wahyu (naqli) atau sistem pengambilan hukum tertentu (istinbath). Wahyu harus secara terusmenerus diwariskan dari satu generasi ke generasi berikutnya melalui teks, sedangkan istinbath harus dilaksanakan dengan bantuan ajaran-ajaran mazhab hukum.

Pemikiran KH. Hasyim Asy'ari dalam fiqh siyasah (tata cara politik dalam Islam), ${ }^{47}$ bahwa fiqh siyasah bisa dikatakan sebagai ilmu politik pemerintahan dan ketatanegaraan dalam Islam yang mengkaji aspek-aspek yang berkaitan dengan dalildalil umum dalam Al-qur'an dan hadits serta tujuan dalam syariat. Pada saat itu KH. Hasyim Asy'ari harus aktif ikut campur dalam urusan kenegaraan, sebab ia khawatir terhadap bangsa Indonesia yang akan terpecah belah. Maka, sikap yang diambil KH. Hasyim Asy'ari adalah ajakan kepada seluruh umat Islam Indonesia untuk bersatu dalam aksi bersama ${ }^{48}$ Menurut KH. Hasim Asy'ari menerangkan bahwa perpecahan merupakan penyebab kelemahan, kekalahan, dan kegagalan di sepanjang zaman. Bahkan, pangkal kehancuran dan kemacetan, sumber keruntuhan dan kebinasaan, dan penyebab kehinaan dan kenistaan.

Ajakan persatuan tersebut disampaikan di berbagai kesempatan mengingat kondisi umat yang terpecah belah ketika itu, dan dibutuhkannya akan persatuan yang mendesak bagi Indonesia. Menurut Nizar alasan ajakan persatuan berdasarkan Pertama, persatuan kebangsaan yang artinya persatuan yang dilandasi dengan kesamaan kebangsaan. Kedua, persatuan keagamaan yaitu persatuan yang dilandasi 201113): 10.

${ }^{47}$ Syaiful Hidayat, 'Tata Negara Dalam Perspektif Fiqh Siyasah', Tafaqqub 1, no. 22 (April

${ }^{48}$ Khusnul Chotimah, 'Aktualisasi Pemikiran KH. M. Hasyim Asy'ari Kenegaraan Dan Kebangsaan’, Jurnal Inovatif 3, no. 2 (July 2018): 131. 
kesamaan agama. Dengan demikian, pemikiran KH. Hasyim Asy'ari mengenai ajakan persatuan dimaksudkan dalam ruang lingkup negara, tujuannya agar cita-cita kebangsaan yang diinginkan dapat terwujud. ${ }^{49}$

\section{Pemikiran Kebangsaan KH. Hasyim Asy'ari}

Pemikiran kebangsaan KH. Hasyim Asy'ari sebenarnya mengarah ke ide-ide politik (figh Siyasab). Secara umum pemikiran politik KH. Hasyim Asy'ari sejalan dengan doktrin politk Sunni sebagaimana yang telah dikembangkan oleh Al-Mawardi dan Al-Ghazali. ${ }^{50}$ menjelaskan pada dasarnya doktrin ini sangat akomodatif terhadap penguasa, hal ini dikarenakan pada saat itu dirumuskannya doktrin ini ketika dunia politk Islam mengalami kemunduran yang pada gilirannya akan memunculkan anggapan bahwa posisi rakyat sangat lemah dan mereka harus tunduk terhadap penguasa. Artinya sejalan dengan sikap KH. Hasyim Asy'ari dan tokoh Nahdlatul Ulama yang lain menunjukan akomodatif pada penguasa, baik yang muslim maupun non-muslim.

Pada masa awal karier kehidupannya, KH. Hasyim Asy'ari bukanlah seorang aktivis politik dan bukan pula musuh penjajah. Ketika itu ia belum peduli untuk menyebarkan ide-ide doktrin politik dan umumnya tidak keberatan dengan kebijakankebijakan penjajah, selama tidak membahayakan keberlangsungan ajaran-ajaran Islam. Khuluq mengatakan dalam kaitan ini, KH. Hasyim Asy'ari tidaklah seperti tokohtokoh nasionalis-sekuler, Soekarno sebagai pendiri Partai Nasional Indonesia dan Presiden, Cokroaminto dan Agus Salim pemimpin Syarekat Islam yang memfokuskan diri pada isu-isu politik dan bergerak secara terbuka selama beberapa tahun untuk kemerdekaan Indonesia. Meskipun demikian, KH. Hasyim Asy'ari dapat dianggap sebagai pemimpin spritual bagi sebagian tokoh politik. Aktivitas politiknya sendiri bersifat low profile sampai akhir hanyatnya. ${ }^{51} \mathrm{KH}$. Hasyim Asy'ari juga tidak pernah secara terbuka bersikap konfrontasi terhadap penjajah. Dengan demikian untuk mengerti lebih dalam pemikiran kebangsaan KH. Hasyim Asy'ari dalam perkembangan politik dan pengaruhnya kepada para pemimpin muslim saat itu harus diperhatikan.

\section{Perjuangan KH. Hasyim Asy'ari dalam Organisasi Nahdlatul Ulama}

Seluruh hidup KH. Hasyim Asy'ari bisa dikatakan hanya dihabiskan untuk mengabdi menyebarkan agama Islam, perkembangan pendidikan dan kemerdekaan Indonesia. Kehidupan kesehariannya dipenuhi dengan kegiatan dakwah dan mengajar di pondok pesantren yang ia dirikan (Tebuireng). Sesekali ia juga disibukkan dengan organisasi perkumpulan para ulama sejawa Timur dan Jawa Tengah yang disebut organisasi keagamaan Nahdlatul Ulama yang mana ia menjabat sebagai Rais Am.

\footnotetext{
${ }^{49}$ Muchamad Coirun Nizar, 'Pemikiran KH. Hasyim Asy'ari tentang Persatuan', Endogami: Jurnal Ilmiah Kajian Antropologi 1, no. 1 (Desember 2017): 63-74, https://doi.org/10.14710/endogami.1.1.68.

${ }^{50}$ Isbandiyah, dkk, 'Konstruksi Sejarah Perjuangan Dan Pemikiran KH Hasyim Asy'ari,' Jurnal Studi Sosial Fkip Unila 1, no. 2 (June 2013): 9.

${ }^{51}$ Khuluq, Tafsir Pemikiran Kebangsaan Dan Keislaman Hadratussyaikh K.H. M. Hasyim Asy'ari, 72.
} 
Setelah KH. Hasyim Asy'ari mengembara ilmu di berbagai Pesantren dan di tanah Hijaz, ia kembali ke Indonesia untuk mendirikan pesantren Tebuireng. Pada 1926, KH. Hasyim Asy'ari bersama muridnya KH. Abdul Wahab Hasbullah mendirikan suatu organisasi tradisionalis yakni Nahdlatul Ulama. Sebelum ia mendirikan oraganisasi NU, meminta izin terlebih dahulu kepada salah satu gurunya yakni KH. Kholil Bangkalan. Setelah mendapat restu dari gurunya ia diberikan sebuah tasbih dan tongkat sebagai simbol tugas dan kepemimpinan atas berdirinya NU. ${ }^{52}$

Tujuan berdirinya NU bukan semata-mata untuk mencari popularitas dan kekuasaan semata. Organisasi Nahdlatul Ulama berusaha mempertahankan nilai-nilai tradisional Islam yang selama ini diikuti dan mulai tergerus dengan adanya pemikiranpemikiran modern..$^{53}$ Nilai-nilai tradisional yang di pandang oleh sejumlah kalangan merupakan ajaran dan metode yang sukses di lakukan oleh walisongo sudah mulai di usik kemapanannya. Oleh karena itu, K.H Hasyim Asy'ari dan sejumlah ulama di Jawa Timur dan Jawa Tengah membuat organisasi yang berusaha melestarikan ajaran tradisional dan tetap bernafaskan ablus sunnab wal jama'ah. ${ }^{54} \mathrm{Hal}$ tersebut berhasil dan sampai sekarang organisasi ini menjadi salah satu organisasi terbesar di Indenesia.

Kelahiran NU selain sebagai upaya menjaga prinsip dan khazanah Islam tradisional dan penetrasi yang dilakukan oleh Islam modernis, juga mengusung motif sosial dalam melakukan pembelaan kepentingan golongan Islam tradisional. NU juga didirikan merupakan wadah perjuangan untuk menentang segala bentuk penjajahan dan merebut kemerdekaan negara Republik Indonesia dari penjajah Belanda dan Jepang, sekaligus aktif melakukan dakwah-dakwahnya untuk senantiasa menjaga kesatuan negara Republik Indonesia dalam wadah NKRI. Motif nasionalisme timbul karena NU lahir dengan niatan kuat untuk menyatukan para ulama dan tokoh-tokoh agama dalam melawan penjajahan. Semangat nasionalisme itu pun terlihat juga dari nama Nahdlatul Ulama itu sendiri yakni "Kebangkitan Para Ulama". NU pimpinan Hadhratus Syaikh K.H. Hasyim Asy'ari sangat nasionalis.

\section{Perjuangan KH. Hasyim Asy'ari Melawan Kolonial Belanda}

KH Hasyim Asy'ari merupakan salah satu tokoh perjuangan yang mewakili umat Islam dalam perlawanan terhadap kolonial Belanda. Penderitaan yang dialami bangsa Indonesia dan pengekangan terhadap kebebasan menjalankan perintah agama, mendorong KH. Hasyim Asy'ari untuk mengeluarkan fatwa tentang jihad melawan

\footnotetext{
${ }^{52}$ Mat Solikhin, 'Gerakan Pemikiran Dan Peran Tiga Ulama NU (K.H. Hasyim Asy'ari, K.H.R. Asnawi Kudus, K. H. Wahhab Hasbullah) Dalam Menegakkan Ahl Al-Sunnah Wal-Jama'ah Annahdliyah Di Jawa Tahun 1926 - 1971', Jurnal Theologia 27, no. 2 (Desember 2016): 341, https://doi.org/10.21580/teo.2016.27.2.1071.

${ }^{53}$ Muhammad Zainal Abidin, "Ulama in Indonesian Urban Society: A View of Their Role and Position in the Change of Age," Jurnal THEOLOGLA 28, no. 2 (February 20, 2018): 235-54, https://doi.org/10.21580/teo.2017.28.2.1863.

${ }^{54}$ Abdurrahman, "Sumbangan Pemikiran Nahdlatul Ulama (NU) Terhadap Modernisasi Pendidikan Islam Di Indonesia,” Jurnal Consilium 4, no. 4 (September 2017).
} 
Belanda. Jihad yang dideklarasikannya dicatat dalam sejarah sebagai jihad kebangsaan. Bangsa Indonesia yang saat itu dalam posisi terjajah mempunyai hak untuk memerdekakan diri dari berbagai penindasan yang dilakukan para penjajah. Sebagai ulama kharismatik dan tokoh umat, maka KH. Hasyim Asy'ari menggelorakan semangat perjuangan untuk menentang penjajahan Belanda terutama dikalangan anak muda atau para santri. Beliau mengajak mereka untuk berjihad melawan penjajah dan menolak kerjasama dengan penjajah tersebut. Gerakan perlawanan ini disambut umat untuk membebaskan mereka dari ketertindasan yang menghinakan menuju kemuliaan yang membahagiakan.

Perjuangan KH. Hasyim Asy'ari melawan penjajah sebenarnya sudah dimulai pada saat menata Pesantren Tebuireng, di mana banyak rintangan, halangan dan hambatan dan pemerintah kolonial Belanda. Pemerintah kolonial Belanda senang melihat kaum Muslim dalam posisi terbelakang sehingga tidak dapat melakukan perlawanan terhadapnya. ${ }^{55}$

Bentuk perjuangan K.H. Hasyim Asy'ari ketika negaranya Indonesia dijajah Belanda adalah ketika beliau berikrar di Multazam, sewaktu melakukan haji untuk kedua kalinya. Beliau berikrar bersama teman-temannya yang bukan hanya berasal dan Indonesia, tapi juga dari Malaysia, Brunei, benua Afrika, dan Timur Tengah. Mereka mengikrarkan diri untuk mengabdikan keilmuan- nya mereka pada kejayaan Islam dan masyarakat di negaranya masing-masing agar segera terlepas dan penjajah. ${ }^{56}$

Misrawi mengemukakan bahwa jihad kebangsaan yang dideklarasikan oleh KH. Hasyim Asy'ari tersebut terbukti sangat efektif dalam membakar patriotisme umat, sehingga para penjajah dapat dilenyapkan dari Bumi Pertiwi. Faktanya, para penjajah menunjukkan sikap intoleransi terhadap rakyat Indonesia. Pesantren Tebuireng merupakan salah satu sasaran tindakan represif penjajah. Pada tahun 1913, Intelijen Belanda membuat sebuah modus licik dengan cara mengirim seorang pencuri ke Tebuireng. Lalu, para santri menangkap pencuri tersebut dan memukulinya hingga tewas. ${ }^{57}$

Jihad menjadi ikatan solidaritas yang mampu mengetuk setiap hati kaum muslim untuk melakukan perlawanan kepada pemerintah kolonial. Konsep ini pertama kali didengungkan pada akhir abad ke-17, ketika kerajaan Mataram dan Banten jatuh ke tangan Belanda. Kaum Muslim Nusantara telah mengenal konsep ini sejak lama, lewat buku-buku tentang Islam atau lewat pengajian-pengajian dan ceramah-ceramah di masjid. Tapi sebelum itu tidak begitu jelas apa makna jihad dan bagaimana menerapkannya. Baru setelah mereka berhadapan secara nyata dengan "kaum kafir londo" arti jihad menjadi jelas. ${ }^{58}$

Belanda tidak tinggal diam dan terus mencari berbagai cara untuk melakukan penindasan terhadap KH. Hasyim Asy'ari. Belanda mengirimkan tentaranya dalam

${ }^{55}$ Muhammad Rijal Fadli and Miftahuddin, 'Dari Pesantren Untuk Negeri: Kiprah Kebangsaan KH. Hasyim Asy'ari', Jurnal Islam Nusantara 3, no. 2 (Desember 2019): 19, https://doi.org/10.33852 / jurnalin.v3i2.138.

${ }^{56}$ Rifai, K.H. Hasyim Asy'ari, 70.

${ }^{57}$ Misrawi, Hadratussyaikh Hasyim Asy'ari, 86.

${ }^{58}$ Bernard H.M Vlekke, Nusantara Sejarah Indonesia (Jakarta: Gramedia, 2011), xi.

Khazanah, Vol. 18 (1), 2020 
jumlah besar untuk menghancurkan fasilitas Pesantren Tebuireng dengan dibakar, baik bangunan maupun kitab-kitab milik pesantren. Bahkan, kitab-kitabnya jugat dibakar. Perlakuan tidak manusiawi seperti itu berlangsung hingga tahun 1940-an. KH. Hasyim Asy'ari dan pesantrennya terus diawasi oleh intelijen-intelijen penjajah. Bahkan, karena sikap keras beliau menyebabkan penjajah akhirnya berusaha membunuhnya dan membakar habis pesantrennya. Namun, hal itu tidak pernah menyurutkan perjuangan beliau, karena dengan segera pesantren itu dibangun kembali dan beliau masih bisa bersikap keras terhadap penjajah.

KH. Hasyim Asy'ari menjabat sebagai ketua federasi organisasi organisasi Islam, MIAI (Majelis Islam A'la Indonesia) pada akhir 1930-an. Beliau berperan dalam penggabungan MIAI dengan gerakan nasionalis lain yang menghasilkan federasi politik GAPI (Gabungan Politik Indonesia) yang menuntut Belanda agar membentuk perwakilan rakyat yang representatif (Indonesia Berparlemen) bagi rakyat pribumi. Beliau juga mengeluarkan fatwa agar umat Islam menolak wajib militer dan pemerintah Belanda dalam usahanya mempersiapkan diri menghadapi Jepang pada 1940-an, serta fatwa lain yang melarang donor darah untuk kepentingan perang Belanda.

KH. Hasyim Asy'ari dianggap sebagai provokator yang cukup berbahaya dalam perjuangan kemerdekaan Indonesia, sehingga seluruh aktivitas yang dijalani KH. Hasyim Asy'ari tidak pernah lepas dan pengawasan Belanda. Dalam situasi tersebut, KH. Hasyim Asy'ari tetap menjalankan segala aktivitas sosial-keagamaannya dengan penuh semangat. KH. Hasyim Asy'ari terus memberikan semangat dan motivasi kepada rakyat Indonesia untuk terus berjuang hingga tetes darah penghabisan.

Perjuangan KH. Hasyim Asy'ari tidak surut, tetapi terus menggelorakan semangat jihad dan berdampak pada bangkitnya perlawanan umat Islam dan pembentukan laskar-laskar jihad, seperti Hizbullah dan Sabilillah dalam perlawanan bersenjata melawan Belanda. Peran KH Hasyim Asy'ari dalam ikut mewujudkan Indonesia merdeka dan berdaulat secara politik tidaklah kecil. Melalui pesantren yang didirikannya, kemudian juga lewat jam'iyah NU, KH. Hasyim Asy'ari menanamkan nasionalisme dan patriotisme sehingga mengobarkan api perlawanan rakyat terhadap kolonialisme yang telah berlangsung berabad-abad lamanya. ${ }^{59}$ Cengkeraman imperialisme dan hegemoni kolonial terhadap rakyat, tidak hanya terbatas pada aspek lahir seperti ekonomi, politik dan sebagainya, tetapi lebih dari itu, telah menguasai kesadaran dan rasionalitas mereka. Oleh karena itu, pendidikan dan dakwah yang digagas oleh KH. Hasyim Asy'ari merupakan sarana yang efektif untuk mengubah kesadaran rakyat dan membangkitkannya dari ketertindasan. Melalui pengajaran dan fatwa-fatwanya, KH. Hasyim Asy'ari membangkitkan kesadaran untuk melawan, dan membebaskan diri dari penjajahan, yang pada akhirnya berhasil menggelorakan revolusi fisik merebut dan mempertahankan kemerdekaan Republik Indonesia.

${ }^{59}$ Solikhin, “Gerakan Pemikiran Dan Peran Tiga Ulama NU (K.H. Hasyim Asy'ari, K.H.R. Asnawi Kudus, K. H. Wahhab Hasbullah) Dalam Menegakkan Ahl Al-Sunnah Wal-Jama’ah Annahdliyah Di Jawa Tahun 1926 - 1971." 


\section{Reaksi KH. Hasyim Asy'ari Terhadap Jepang}

Reaksi perlawanan yang ditunjukkan oleh KH. Hasyim Asy'ari terhadap kolonial Belanda juga ditunjukkan ketika Jepang menjajah Indonesia. Ketika Jepang berkuasa, umat Islam masih harus berhadapan dengan pemerintah yang zalim, tetapi yang melihat mereka dengan cara pandang yang sangat berbeda. Begitu Jepang berhasil mengusir Belanda keluar dari Jawa, prioritas pertama mereka adalah mengontrol warga, melarang segala aktivitas politik, memadamkan setiap gejolak dan mengatur ketertiban masyarakat. Ketika mereka merasa bahwa prioritas tersebut telah tercapai, mereka mengalihkan prioritas mereka untuk memobilisasi rakyat Jawa, sehingga memperkokoh pertahanan Jepang terhadap kemungkinan serangan balasan dan tentara Sekutu yang pada akhirnya tidak terjadi. ${ }^{60}$

Bentuk reaksi KH. Hasyim Asy'ari sebagai pejuang sejati dan pahlawan terhadap pendudukan Jepang adalah ketika ia menolak segala bentuk niponisasi, seperti menyanyikan lagu Kimigayo dan mengibarkan bendera Jepang serta melakukan Seikerei (kewajiban memberikan penghormatan dengan cara membungkukkan badan ke arah Tokyo setiap pukul 07.00 sebagai simbol penghormatan kepada Kaisar Hirohito dan ketundukan kepada Dewa Matahari). ${ }^{61}$ Sikap tersebut mendapatkan respons represif dari tentara Jepang, akibatnya KH. Hasyim Asy'ari serta sejumlah putra dan sahabatnya diringkus dalam penjara, ia dipenjara selama tiga bulan.

Bustami menjelaskan perintah tersebut bukan hanya ditolak oleh KH. Hasyim Asy'ari, namun beliau juga menyerukan kepada seluruh penduduk Indonesia terutama warga NU untuk tidak melakukannya karena dianggap sama dengan perbuatan menyekutukan Tuhan. Maka terjadilah perlawanan secara massif terutama di kalangan pesantren, dan bahkan pengurus NU perlu bertemu secara khusus untuk membahas penahanan tersebut serta membahas penentuan sikap akan upaya perlawanan terhadap Jepang. ${ }^{62}$ Pada Agustus 1942 Jepang kemudian membebaskan KH. Hasyim Asy'ari setelah menyadari bahwa tindakannya itu justru kontraproduktif dan menimbulkan keresahan yang luas terutama di kalangan ulama dan warga NU. ${ }^{63}$

Reaksi tegas KH. Hasyim Asy'ari mengakibatkan Jepang marah besar sehingga ia dipenjara. Kabarnya, la dipindah-pindahkan dari penjara Jombang, Mojokerto, lalu ke Bubutan, Surabaya. Perlakuan Jepang terhadap KH. Hasyim Asy'ari begitu kasar, jari tangannya patah sehingga tidak bisa digerakkan. Penahanan tersebut berakibat pada terhentinya aktivitas Pesantren Tebuireng, termasuk aktivitas

${ }^{60}$ M.C. Ricklefs, Mengislamkan Jawa: Sejarah Islamisasi Di Jawa Dan Penentangnya Dari 1930 Sampai Sekarang (Jakarta: Serambi Ilmu Pustaka, 2012), 121.

${ }^{61}$ Faisal Ismali, 'The Nahdlatul Ulama: Its Early History and Contribution to the Establishment of Indonesian State', Journal of Indonesian Islam5 5, no. 2 (March 2011): 258, https://doi.org/10.15642/JIIS.2011.5.2.

${ }^{62}$ Abdul Latif Bustami, Resolusi Jihad 'Perjuangan Ulama: Dan Menegakekan Agama Hingga Negara (Jombang: Pustaka Tebuireng, 2015), 133.

63I Saputra, "Resolusi Jihad: Nasionalisme Kaum Santri Menuju Indonesia Merdeka," Jurnal Islam Nusantara 3, no. 1 (June 2019): 205-37, https://doi.org/10.33852/jurnalin.v3i1.128.

Khazanah, Vol. 18 (1), 2020 
pendidikan, sebagai bentuk keprihatinan terhadap musibah yang dialami KH. Hasyim Asy'ari. ${ }^{64}$ Istrinya, Nyai Masrurah, pun mengungsi ke Pesantren Denanyar selama suaminya berada di penjara. KH. Hasyim Asy'ari memberi fatwa keharaman menyerupai orang kafir (penjajah Belanda) dalam berpakaian, dan pada era penjajahan Jepang, ia juga pernah ditangkap dan dipenjarakan atas fatwanya mengharamkan Seikerei (kewajiban membungkukkan badan menghadap ke arah timur demi menghormati kaisar Jepang sebagai titisan Dewa Matahari). Semuanya itu, merupakan contoh bagaimana KH. Hasyim Asy'ari dan ulama-ulama pesantren berperan menanamkan jiwa kebangsaan dan patriotik mengusir penjajah dari negeri ini.

Ketokohan KH. Hasyim Asy'ari diakui oleh semua kalangan, bahkan pemikirannya dapat diterima oleh kalangan umat Islam dari berbagai organisasi yang sebelumnya berbeda orientasi ideologis, tetapi menginspirasi dan sekaligus diterima sebagai landasan bersikap menghadapi kekuatan imperialisme saat itu. Kredibilitas KH. Hasyim Asy'ari merupakan perpaduan antara karakter keulamaannya yang kuat, juga komitmen kebangsaan, kepemimpinan, dan wawasan kenegaraannya yang luas sebagai rasa cintanya kepada negara. Sehingga fatwa jihad yang ia keluarkan, mencerminkan dengan jelas komitmennya yang kuat pada kemaslahatan umat Islam.

\section{Simpulan}

KH. Hasyim Asy'ari mempunyai pemikiran dan peranan yang cukup besar dalam berbagai hal, diantaranya di bidang keislaman dan kebangsaan. Mengenai pemikiran keislaman KH. Hasyim Asy'ari, ia mempunyai pemikiran keislaman yang bercorak pada Islam tradisional, diantara pemikiran keislaman KH. Hasyim Asy'ari adalah dalam bidang tasawnf (sufisme), bidang teologi, dan bidang fiqh. Sedangkan pemikiran KH. Hasyim Asy'ari mengenai kebangsaan mengacu pada ide-ide politiknya yang dapat menyatukan umat Islam Indonesia untuk melawan Kolonialisme, seperti mendirikan Pesantren, Ormas NU, dan organisasi lainnya untuk wadah menjaga persatuan. Pada masa awal karier kehidupannya, KH. Hasyim Asy'ari bukanlah seorang aktivis politik dan bukan pula musuh penjajah dan belum peduli untuk menyebarkan ide-ide doktrin politik dan umumnya tidak keberatan dengan kebijakan-kebijakan penjajah, selama tidak membahayakan keberlangsungan ajaran-ajaran Islam. Artinya bahwa pemikiran kebangsaannya hanya bersifat low profil tidak seperti para tokoh nasional-sekuler. Ia tidak menampakkan tindakannya terhadap penjajah, namun apapun setiap kebijakannya/petuahnya dapat membahayakan keberadaan bagi penjajah, sehingga Ia selalu mendapat ancaman dari penjajah. Namun, ancaman itu tidak mengendorkan semangatnya untuk terus melakukan kebijakan untuk kemaslahatan umat Islam Indonesia.

Pemikiran keislaman dan kebangsaan KH. Hasyim Asy'ari sampai saat ini patut diamalkan dan diteladani untuk kehidupan saat ini. Sebab dewasa ini masih ada kelompok-kelompok tertentu yang ingin memisahkan antara keislaman dan

${ }^{64}$ Zainul Milal Bizawie, Laskar Ulama -Santri Dan Resolusi Jihad Garda Depan Menegakekan Indonesia (1945-1949) (Jakarta: Pustaka Compas, 2014), 201. 
kebangsaan yang dikhawatirkan dapat memicu pecah belahnya umat. Padahal masalah keislaman dan kebangsaan tidak serta merta dipertentangkan begitu saja, sehingga keduanya harus saling melengkapi demi kesejahteraan bangsa dan kenyaman dalam menjalankan perintah agama.

\section{Daftar Pustaka}

Abdelaal, Mohamed A. "Taqlīd V. Ijtihād: The Rise Of Taqlīd As The Secondary Judicial Approach In Islamic Jurisprudence." The Journal Jurisprudence 5, no. 4 (2012).

Abdurrahman. "Sumbangan Pemikiran Nahdlatul Ulama (NU) Terhadap Modernisasi Pendidikan Islam Di Indonesia." Jurnal Consilium 4, no. 4 (September 2017).

Abidin, Muhammad Zainal. "Ulama in Indonesian Urban Society: A View of Their Role and Position in the Change of Age." Jurnal THEOLOGLA 28, no. 2 (February 20, 2018): 235-54. https://doi.org/10.21580/teo.2017.28.2.1863.

Achmad Shiddiq. Khithttah Nadliyah. Surabaya: Balai Buku, 1979.

A'dlom, Syamsul. "Kiprah KH. Hasyim Asy'ari dalam Mengembangkan Pendidikan Agama Islam." JURNAL PUSAKA 2, no. 1 (February 2014): 14.

Aguk Irawan Mn. Penakluk Badai: Novel Biografi K.H. Hasyim Asy'ari. Cet. 1. Depok: Global Media Utama, 2012.

Akarhanaf. Kiai Hasjim Asj'ari Bapak Umat Islam Indonesia. Jombang: Pesantren Tebuireng, 1950.

Al-Farizi, Mudrik. "Ijtihad, Taqlid Dan Talfiq." Al-Mabsut Jurnal Studi Islam Dan Sosial 8, no. 1 (April 2014): 209-20.

Arifin, Zainal, and Muhammad Fathoni. "Jejak Pemikiran Syaikh Nawawi Al-Banteni Terhadap Pemikiran Teologi, Fiqih Dan Tasawuf Hadratusy Syaikh KH. Hasyim Asy'ari." Al Qodiri: Journal of Education, Social and Religious 16, no. 1 (April 2019): 46-56. https://doi.org/10.1234/al\%20qodiri.v16i1.3313.

Bizawie, Zainul Milal. Laskar Ulama -Santri Dan Resolusi Jihad Garda Depan Menegakkan Indonesia (1945-1949). Jakarta: Pustaka Compas, 2014.

Bruinessen, Martien Van. Kitab Kuning, Pesantren Dan Tarekat. Bandung: Mizan, 1995.

- NU, Tradisi, Relasi-Relasi Kuasa, Pencarian Wacana Baru. Yogyakarta: LKiS, n.d.

Budi Harianto. "Relasi Teologi Aswaja Dengan Ham Perspektif Kiai Said Aqil Siroj." HUMANISTIKA: Jurnal Keislaman 4, no. 2 (November 2019): 129-44. https://doi.org/10.36835/humanistika.v4i2.34.

Burhani, Ahmad Najib. “"'Al-Tawassut Wal-I'tidal: The NU and Moderatism in Indonesia Islam." Asian Journal of Social Science 40, no. 5 (November 2012): 564-81. https://doi.org/10.1163/15685314-12341262.

Bustami, Abdul Latif. Resolusi Jihad "Perjuangan Ulama: Dan Menegakean Agama Hingga Negara. Jombang: Pustaka Tebuireng, 2015. 
Chotimah, Khusnul. "Aktualisasi Pemikiran KH. M. Hasyim Asy'ari Kenegaraan Dan Kebangsaan." Jurnal Inovatif 3, no. 2 (July 2018): 128-40.

Fadli, Muhammad Rijal, and Bobi Hidayat. KH. Hasyim Asy'ari Dan Resolusi Jihad Dalam Usaha Mempertahankan Memerdekaan Indonesia. Metro, Lampung: Laduny Alifatama, 2018.

Fadli, Muhammad Rijal, and Miftahuddin. "Dari Pesantren Untuk Negeri: Kiprah Kebangsaan KH. Hasyim Asy'ari." Jurnal Islam Nusantara 3, no. 2 (Desember 2019): 1-27. https://doi.org/10.33852 / jurnalin.v3i2.138.

Fata, Ahmad Khoirul, and M Ainun Najib. "Kontekstualisasi Pemikiran KH. Hasyim Asy'ari Tentang Persatuan Umat Islam." MIQOT: Jurnal Ilmu-ilmu Keislaman 38, no. 2 (Desember 2014): 319-34. https://doi.org/10.30821/miqot.v38i2.65.

Hadi, Abdul. K.H. Hasyim Asy'ari: Sehimpun Cerita, Cinta, Dan Karya Maba Guru Ulama Nusantara. Cetakan pertama. Baturetno, Banguntapan, Yogyakarta: Diva Press, 2018.

Hadziq (ed), Muhammad Isham. At-Ta'rif Bi al-Muallif. Dalam Hasyim Asy'ari, Adab alAlim Wa al-Muta'allim. Jombang: Maktabat al-Turats al-Islami, 1995.

Hakam, Abdullah. "KH. Hasyim Asy'ari Dan Urgensi Riyadah Dalam Tasawuf Akhlaqi." Teosofi: Jurnal Tasawnf Dan Pemikiran Islam 4, no. 1 (June 2014): 144 66. https://doi.org/10.15642/teosofi.2014.4.1.145-166.

Herry, Mohammad. Tokoh-Tokoh Islam Yang Berpengaruh Abad 20. Jakarta: Gema Insani, 2006.

Hidayat, Syaiful. “Tata Negara Dalam Perspektif Fiqh Siyasah.” Tafaqquh 1, no. 22 (April 201113): 2-15.

Isbandiyah, dkk. "Konstruksi Sejarah Perjuangan Dan Pemikiran KH Hasyim Asy'ari,." Jurnal Studi Sosial Fkip Unila 1, no. 2 (June 2013): 1-12.

Ismali, Faisal. "The Nahdlatul Ulama: Its Early History and Contribution to the Establishment of Indonesian State." Journal of Indonesian Islam5 5, no. 2 (March 2011): 247-81. https://doi.org/10.15642/JIIS.2011.5.2.

Khuluq, Lathiful. Fajar kebangunan ulama: biografi K.H. Hasyim Asy'ari. Cet. VI. Yogyakarta: LKiS, 2013.

. "K.H. Hasyim Asy'ari's Contribution to Indonesian Independence." Studia Islamika 5, no. 1 (April 1998): 41-67. https://doi.org/10.15408/sdi.v5i1.760.

. Tafsir Pemikiran Kebangsaan Dan Keislaman Hadratussyaikh K.H. M. Hasyim Asy'ari. Jombang, Jawa Timur: Penerbit dan distribusi, Penerbit Tebuireng, 2018.

Kurdi, Sulaiman. "MASYARAKAT IDEAL DALAM AL-QUR'AN (Pergulatan Pemikiran Ideologi Negara Dalam Islam Antara Formalistik Dan Substansialistik)." Kharanab: Jurnal Studi Islam Dan Humaniora 13, no. 2 (May 26, 2017): 41. https://doi.org/10.18592/khazanah.v14i1.1049.

Laffan, Michael. "The Fatwa Debated ? Shura in One Indonesia Context," Islamic Law and Society." Islamic Law and Society 12, no. 1 (June 2005): 1-23. https://doi.org/10.1525/sp.2007.54. 
Ma'aruf (ed), Asmani Jamal. Pemikiran KH. Hasyim Asy'ari Tentang Agama, Perempuan Dan Kemasayarakatan. Yogyakarta: Aswaja Pressindo, 2018.

Madjid, Nurcholis. Islam, Iman Dan Ibsan Sebagai Trilogi Ajaran Islam. Jakarta: Yayasan Paramadina, 1994.

Margono, Hartono. "KH. Hasyim Asy'ari dan Nahdlatul Ulama: Perkembangan Awal dan Kontemporer" 26, no. 3 (July 2011): 335-49.

Misno, Abdurrahman. "Redefinisi Ijtihad Dan Taklid." Al-Mashlahah Jumal Hukum Dan Pranata Sosial Islam 2, no. 4 (Desember 2014): 12-22. https://doi.org/10.30868/am.v2i04.133.

Misrawi, Zuhairi. Hadratussyaikh Hasyim Asy'ari: Moderasi, Keumatan, Dan Kebangsaan. Jakarta: Penerbit Buku Kompas, 2010.

Muhaemin. "Teologi Aswaja Nahdhatul Ulama Di Era Modern: Studi Atas Pemikiran Kyai Hasyim Asy'ari.” Jurnal Diskursus Islam 1, no. 2 (January 2013): 315-28. https://doi.org/10.24252/jdi.v1i2.6634.

Ni'am, Syamsun. Wasiat Tarekat: Hadratus Syaikh Hasyim Asy'ari. Cet. 1. Sleman, Yogyakarta: Ar-Ruzz Media, 2011.

Nizar, Muchamad Coirun. "Pemikiran KH. Hasyim Asy'ari tentang Persatuan." Endogami: Jurnal Ilmiah Kajian Antropologi 1, no. 1 (Desember 2017): 63-74. https://doi.org/10.14710/endogami.1.1.63-74.

N.U (Organisasi). Aswaja An-Nabdliyab: Ajaran Ablussunah Wal Jama'ah Yang Berlaku Di Lingkungan Nabdlatul Ulama. Surabaya: Khalista, 2007.

Nurhadi, Rofiq. "Pendidikan Nasionalisme-Agamis dalam Pandangan K.H. Ahmad Dahlan dan K.H. Hasyim Asyfari." CAKRAW ALA: Jurnal Studi Islam 12, no. 2 (Desember 2017): 121-32. https://doi.org/10.31603/cakrawala.v12i2.1716.

Rahman (ed), Fazlur. "Revival and Reform in Islam. In Cambridge History of Islam," Vol. 2. Cambridge: Cambridge University Press, 1970.

Ricklefs, M.C. Mengislamkan Jawa: Sejarah Islamisasi Di Jawa Dan Penentangnya Dari 1930 Sampai Sekarang. Jakarta: Serambi Ilmu Pustaka, 2012.

Rifai, Muhamad. K.H. Hasyim Asy'ari: Biografi Singkat, 1871-1947. Cet. 1. Yogyakarta: Garasi : Didistribusikan oleh ar-Ruzz Media, 2009.

Rofiq, Ahmad Choirul. "Argumentasi Hasyim Asy'ari Dalam Penetapan Ahlus Sunnah Wal Jama'ah Sebagai Teologi Nahdlatul Ulama." Jurnal Kontemplasi 5, no. 1 (Agustus 2017): 22-47. https://doi.org/10.21274/kontem.2017.5.1.

Rupadha, I Komang. "Memahami Metode Analisis Pasangan Bibliografi (Bibliographic Coupling) dan Ko-Sitasi (Co-Citation) serta Manfaatnya untuk Penelitian Kepustakaan." Lentera Pustaka: Jurnal Kajian Ilmu Perpustakaan, Informasi dan Kearsipan 2, no. 1 (Oktober 2016): 68. https://doi.org/10.14710/lenpust.v2i1.12358.

Saleh, Fauzan. "The School of Ahl Al-Sunnah Wa Al-Jama'ah And The Attachment of Indonesian Muslims to Its Doctrines." Journal of Indonesian Islam 2, no. 1 (June 2008): 16-38. https://doi.org/10.15642/JIIS.2008.2.1. 
Saputra, I. "Resolusi Jihad: Nasionalisme Kaum Santri Menuju Indonesia Merdeka." Jurnal Islam Nusantara 3, no. 1 (June 2019): 205-37. https://doi.org/10.33852/jurnalin.v3i1.128.

Simandjuntak, Bungaran Anthonius, and Soedjito Sosrodihardjo. Metode Penelitian Sosial (Edisi Revisi). Jakarta: Yayasan Pustaka Obor Indonesia, 2014.

Solikhin, Mat. "Gerakan Pemikiran Dan Peran Tiga Ulama NU (K.H. Hasyim Asy'ari, K.H.R. Asnawi Kudus, K. H. Wahhab Hasbullah) Dalam Menegakkan Ahl Al-Sunnah Wal-Jama'ah Annahdliyah Di Jawa Tahun 1926 - 1971." Jurnal Theologia 27, no. 2 (Desember 2016): 331-61. https://doi.org/10.21580/teo.2016.27.2.1071.

Tim Pusat Kajian Pemikiran KH. Hasyim Asy'ari Tebuireng. Sikap Keislaman Dan Kebangsaan Hadratussyaikh KH. M. Hasyim Asy'ari. Cetakan I. Jombang, Indonesia: Pustaka Tebuireng, 2018.

Vlekke, Bernard H.M. Nusantara Sejarah Indonesia. Jakarta: Gramedia, 2011.

Zed, Mestika. Metode Penelitian Kepustakaaan. Jakarta: Yayasan Pustaka Obor Indonesia, 2004.

Zutas, Kambali. "Literacy Tradition in Islamic Education in Colonial Period (Sheikh Nawawi al Bantani, Kiai Sholeh Darat, and KH Hasyim Asy'ari)." Al-Hayat 1, no. 1 (Oktober 2017): 16-31. https://alhayat.or.id/index.php/alhayat/article/view/2. 